\title{
Dietary Supplementation of Different Levels of Phytogenic Feed Additive in Broiler Diets: The Dynamics of Growth Performance, Caecal Microbiota, and Intestinal Morphometry
}

\section{-Author(s)}

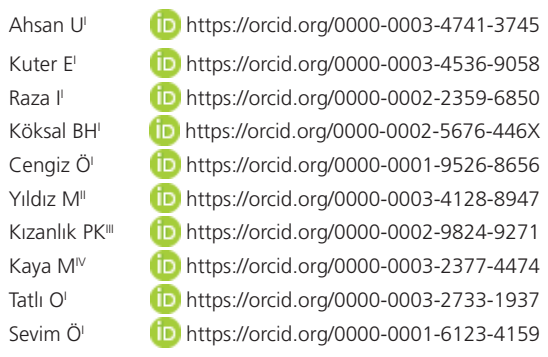

Department of Animal Nutrition and Nutritional Diseases, Faculty of Veterinary Medicine, Adnan Menderes University, Işıklı, Aydın 09016, Turkey. Department of Occupational Health and Safety, School of Applied Sciences, Canakkale Onsekiz Mart University, Çanakkale 17020, Turkey.

III Department of Food Hygiene and Technology, Faculty of Veterinary Medicine, Adnan Menderes University, Işıklı, Aydın 09016, Turkey.

iv Department of Animal Science, Faculty of Veterinary Medicine, Adnan Menderes University, Işıklı, Aydın 09016, Turkey.

\section{-Mail Address}

Corresponding author e-mail address Umair Ahsan

Department of Animal Nutrition and Nutritional Diseases, Faculty of Veterinary Medicine, Adnan Menderes University, Işıklı, Aydın, 09016, Turkey.

Phone: (+90) 5522061246

Email: umair.asawar46@gmail.com

\section{nKeywords}

Broilers, intestinal microbiota, intestinal morphology, performance, phytogenic feed additive.

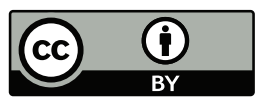

Submitted: 08/January/2018

Approved: 10/June/2018

\section{ABSTRACT}

The present study was conducted to investigate the influence of different levels of dietary phytogenic feed additive (PFA) on growth performance, caecal microbiota, and intestinal morphology of broilers. A total of 480 Ross-308 one-day-old male broilers chicks (body weight $43 \pm 3 \mathrm{~g}$ ) were randomly assigned to 32 replicate pens of four experimental groups, each experimental group consisting of 8 replicates (each replicate pen consisting of 15 chicks). A basal diet was formulated based on corn and soybean meal that was fed to the control group. Other dietary treatments received a commercial PFA at $100 \mathrm{mg} / \mathrm{kg}$ (PFA 100), $125 \mathrm{mg} / \mathrm{kg}$ (PFA125), and $150 \mathrm{mg} / \mathrm{kg}$ (PFA150). Body weight gain, feed intake, and feed conversion rate of broilers were recorded on 1-21, 22-42, and 1-42 days of age. One bird was slaughtered on the $21^{\text {st }}$ and $42^{\text {nd }}$ days and caecal contents were aseptically collected. Jejunal tissue samples were also collected on the same days. Total aerobic bacteria, coliforms, Escherichia coli, and lactobacilli were counted in the caecal contents. Villus height, villus diameter, crypt depth, muscular thickness, and goblet cell number per villus were recorded. There was no difference among the dietary treatments for growth performance and caecal microbe populations at any phase. However, the dietary PFA supplementation increased the villus height, villus width, muscularis thickness, and reduced the crypt depth and goblet cell number per villus in broilers compared to those fed control diets. In conclusion, this study suggests that dietary supplementation of a PFA consisting of blend of different spices and essential oils did not improve growth performance and caecal microbial populations despite a positive improvement in the jejunal morphometry of broilers.

\section{INTRODUCTION}

Sub-therapeutic levels of antibiotic growth promoters (AGPs) remained in practice for more than 50 years to achieve the growth targets until questioned for growing concerns to antibiotic resistance (Kabir, 2009) and decreasing efficacy of antibiotics used for medical purposes (Dibner \& Richards, 2005). New pathogens have emerged over the last 25 years, some of them prompted from animals, probably a consequence of irrational use of antibiotics. Most of the pathogenic organisms of medical importance seem to have crossed the species barrier from the animals (Ahsan et al., 2016). The use of AGPs is, therefore, being repressed by public that resulted in a complete ban on the use of in-feed AGPs in 2006 by the EU (Vesna et al., 2007). This has attracted the scientists' consideration to develop the alternatives to AGPs in animal nutrition. Phytogenic feed additives (PFAs) have recently gained the attention with their prospective among such alternatives to spare the use of AGPs (Murugesan et al., 2015; Wati et al., 2015). The botanical products with their source belonging to herbs, spices, 
Ahsan U, Kuter E, Raza I, Köksal BH, Cengiz Ö, Yıldız M, Kızanlık PK, Kaya M, Tatlı O, Sevim Ö
Dietary Supplementation of Different Levels of Phytogenic Feed Additive in Broiler Diets: The Dynamics of Growth Performance, Caecal Microbiota, and Intestinal Morphometry essential oils, or oleoresins are referred to as PFAs. Herbs and spices are commonly used as whole plant or their parts. Essential oils are secondary metabolites of odoriferous plants, that have higher biological functions compared with raw materials from which it is derived (Yitbarek, 2015). Usually, the essential oils are comprised of two main compounds i.e. terpenoids and phenylpropanes (Lee et al., 2004). These phytogenic compounds consist of many bioactive biomolecules such as anethole, allicin, allyl-isothiocyanate, cineole, carvacrol, capsaicin, linalool, piperine, and thymol that possess numerous beneficial properties in poultry health and growth performance (Ruberto et al., 2002; Burt, 2004; Puvaca, 2008; Windisch et al., 2008; Yang et al., 2009; Applegate et al., 2010; Hippenstiel et al., 2011; Puvaca et al., 2013).

PFA have been known to improve the performance (Jamroz \& Kamel, 2002; Ciftci et al., 2005; Windisch et al., 2008; Hong et al., 2012), nutrient digestibility (Hernandez et al., 2004; Amad et al., 2011; Mountzouris et al., 2011), digestive enzyme activity (Windisch et al., 2008), and reduce the pathogenic bacterial population (Brenes \& Roura, 2010; Reisinger et al., 2011) in broilers. Despite these improvements and beneficial effects, some studies have reported no impact, or negative impact on performance, gut morphology, and gut microbiota (Muhl \& Liebert, 2007; Abildgaard et al., 2010; Hafeez et al., 2016). Buchannan et al. (2008) reported that the wide range of composition of PFAs may improve or decline the growth performance of broilers. This may be attributed to the variations in the chemical compositions of PFAs that is governed by different factors including location or origin, plant species, growth stage, harvesting time, soil type, climate and stress condition, cultivation practices, fertilization, and irrigation (Daferera et al., 2003; Yitbarek, 2015). Moreover, the composition of bioactive biomolecules in PFAs also varies depending on the parts of the plant used such as seeds, leaf, wood, or bark (Yitbarek, 2015). In addition, the biological properties of PFAs differ based on the source (plant) from which they are extracted (Lawrence ad Reynolds, 1984; Jang et al., 2004; 2007). The composition of PFAs plays a very important role in determining the effectiveness when they are blended due to the fact that bioactive molecules may behave differently when fed as a blend compared to when fed alone (Jang et al., 2004; 2007). Despite the substantial attention being given to use a combination of phytogenic extracts, the results have been inconsistent in terms of their efficacy. There is a need to optimize the dietary supplementation levels of PFAs. Therefore, we hypothesized that gradual increasing levels of a dietary phytogenic product containing a mixture of different essential oils and parts of plants that may help overcome the distorted responses of dietary PFAs. Probably, the inclusion levels of PFAs would be different for various criterions like maximum growth performance, better gut morphology and gut ecosystem, and microbiota. Hence, the aim of the present study was to evaluate the effect of different levels of dietary PFAs on growth performance, intestinal microbiota, and intestinal morphology of broilers.

\section{MATERIALS AND METHODS}

The present study was carried out at the poultry research and experimental unit of the Department of Animal Nutrition and Nutritional Diseases, Faculty of Veterinary Medicine, Adnan Menderes University, Aydın, Turkey. A written approval was obtained from the animal care and use committee of Adnan Menderes University prior to conduct the study (letter No. 64583101/2015/128).

\section{Management of birds}

The experimental area was thoroughly cleaned, fumigated, well heated at a constant temperature of 32 ${ }^{\circ} \mathrm{C}$ a week before the arrival of the chicks. A total of four hundred eighty male ROSS 308 one-d-old broiler chicks were obtained from a local commercial hatchery located nearby Aydın. The chicks ranging their body weight $43 \pm 3 \mathrm{~g}$ were randomly allocated to 32 replicate pens in four equal experimental groups, each consisting of 8 replicate pens with 15 chicks in each pen. The trial lasted for 42 days. Each replicate pen provided a floor space of $0.07 \mathrm{~m}^{2} / \mathrm{bird}$. Birds were allowed ad libitum access to feed through floor feeders during starter period ( $d 1$ to 10) and tube feeders from d 11 and onwards. Each pen was equipped with three nipple drinkers. A deep layer of wood shavings with 6 to $8 \mathrm{~cm}$ height served as bedding material. Fluorescence lights were illuminated during the dark period of the day so as to provide a continuous light. The temperature was maintained at $32{ }^{\circ} \mathrm{C}$ in the first week that was reduced $0.5^{\circ} \mathrm{C}$ per day onwards in order to attain a constant temperature of $24^{\circ} \mathrm{C}$. Relative humidity was maintained between 50 to $60 \%$ throughout the study period.

\section{Experimental design and dietary treatments}

Corn/soybean meal-based basal diets were formulated (Table 1) for starter (d 1-10), grower (d 11-24), and finisher (d 25-42) according to the 
Ahsan U, Kuter E, Raza I, Köksal BH, Cengiz Ö, Yıldız M, Kızanlık PK, Kaya M, Tatlı O, Sevim Ö
Dietary Supplementation of Different Levels of Phytogenic Feed Additive in Broiler Diets: The Dynamics of Growth Performance, Caecal Microbiota, and Intestinal Morphometry recommendations by Aviagen (2014). Basal diet without supplementation was randomly fed to one of the four experimental groups defined as control group. The other experimental groups were fed the basaldiet supplemented with the phytogenic product Digestarom $^{\circledR}$ (BIOMIN Holding GmbH, Getzersdorf, Austria) at $100 \mathrm{mg} / \mathrm{kg}$ (PFA100), $125 \mathrm{mg} / \mathrm{kg}$ (PFA125), and $150 \mathrm{mg} / \mathrm{kg}$ (PFA150). Digestarom ${ }^{\circledR}$ is a powdery blend of essential oils, spices, and functional flavours. Each $\mathrm{kg}$ of Digestarom ${ }^{\circledR}$ contains cinnamon $20 \mathrm{~g}$, cumin $20 \mathrm{~g}$, peppermint oil $170 \mathrm{~g}$, garlic oil $150 \mathrm{~g}$, anise oil 50 $\mathrm{g}$, fennel oil $40 \mathrm{~g}$, and $\mathrm{SiO}_{2}$ and $\mathrm{NaCl}$ as carrier.

Table 1 - Composition of basal diets for broiler's starter, grower, and finisher phases.

\begin{tabular}{lccc}
\hline \multirow{2}{*}{ Ingredients } & Starter & Grower & Finisher \\
\cline { 2 - 4 } & \multicolumn{3}{c}{$\%$} \\
\hline Corn & 55.63 & 56.15 & 33.50 \\
Soybean meal (48\% CP) & 37.50 & 36.00 & 33.50 \\
\hline Vegetable oil & 2.50 & 4.15 & 4.25 \\
Limestone & 0.89 & 0.85 & 0.80 \\
\hline Dicalcium phosphate & 2.30 & 2.00 & 1.73 \\
Salt & 0.35 & 0.35 & 0.35 \\
\hline DL-Methionine & 0.37 & 0.25 & 0.12 \\
L-Lysine sulphate & 0.21 & - & - \\
Vitamin-mineral premix ${ }^{1}$ & 0.25 & 0.25 & 0.25 \\
\hline Nutrient Composition of Diets (\%) & \multicolumn{3}{|c}{} \\
\hline Crude protein & 21.75 & 20.89 & 19.92 \\
Metabolizable energy (Kcal/kg) (Calculated) & 2910 & 3029 & 3070 \\
\hline Crude fiber & 3.47 & 3.39 & 3.30 \\
Crude ash & 5.70 & 5.33 & 4.95 \\
\hline Calcium & 0.97 & 0.88 & 0.79 \\
\hline Available phosphorus & 0.54 & 0.48 & 0.43 \\
\hline Digestible lysine (Calculated) & 1.17 & 1.02 & 0.96 \\
\hline Digestible methionine (Calculated) & 0.66 & 0.54 & 0.40 \\
\hline
\end{tabular}

'Vitamin and mineral premix (per $\mathrm{kg}$ of diet): retinol acetate, $1706 \mathrm{mg}$; cholecalciferol, $41 \mathrm{mg}$; DL- $\alpha$-tocopherol, $27 \mathrm{mg}$; menadione, $0.99 \mathrm{mg}$; cobalamin, $0.015 \mathrm{mg}$; folic acid, $0.8 \mathrm{mg}$ : D-pantothenic acid, $15 \mathrm{mg}$; riboflavin, $5.4 \mathrm{mg}$; niacin, $45 \mathrm{mg}$; thiamine, $2.7 \mathrm{mg}$; D-biotin, $0.07 \mathrm{mg}$; pyridoxine, $5.3 \mathrm{mg}$; manganese, $90 \mathrm{mg}$; zinc, $83 \mathrm{mg}$; iron, $121 \mathrm{mg}$; copper, $12 \mathrm{mg}$; iodine, $0.5 \mathrm{mg}$; selenium, $0.3 \mathrm{mg}$

\section{Growth performance}

Weekly pen body weight (BW) and feed intake (FI) were recorded using an electrical weight balance with minimum accuracy of $\pm 1 \mathrm{~g}$. Body weight gain (BWG) and feed conversion ratio (FCR) were calculated for each pen. BW of the dead birds was added in the pen weight in order to adjust the FCR. BWG, Fl, and FCR were reported for the phases comprising the days $1-21,22-42$, and 1-42.

\section{Caecal microbe count}

On $d 21$ and 42 of the experiment, one bird from each pen ( 8 birds per experimental group) was randomly selected for slaughtering. The birds were slaughtered in a clean slaughter room by cutting the jugular vein. Intestines were exposed following the removal of feathers. Caecal digesta samples were aseptically collected from one bird in each replicate (8 samples per treatment) slaughtered for sampling at $d 21$ and 42 of the experiment. For this purpose, the caeca were ligated and carefully hand-stripped into sterile plastic bags. In the present study, total aerobic bacteria, Escherichia coli, coliforms, and lactobacilli were enumerated in the caecal digesta samples according to the procedures previously described by Cengiz et al. (2012). The caecal digesta samples were appropriately stored at $-80{ }^{\circ} \mathrm{C}$. At the time of microbiological analysis, the samples were thawed and immediately 10 -fold diluted with sterile ice-cold anoxic phosphate buffered saline followed by homogenisation in stomacher for $3 \mathrm{~min}$ (Bagmixer 100 Minimix, Interscience, Arpents, France). In order to count the bacterial populations, $10^{-1}$ to $10^{-7}$ serial dilutions were prepared in buffered peptone water followed by culturing of each dilution on to the selective media. Nutrient, de Man Rogosa Sharpe, violet red bile lactose, and MacConkey agar (Oxoid ${ }^{\mathrm{TM}}$, Hampshire, UK) were used for total aerobic bacteria, lactobacilli, coliform, and E. coli count, respectively. The culture plates were subsequently incubated at $37^{\circ} \mathrm{C}$ for $24 \mathrm{~h}$ for total aerobic bacteria, E. coli, and coliforms. The culture plates intended for lactobacilli count were incubated at $30{ }^{\circ} \mathrm{C}$ in a microaerobic environment. The colony forming units (cfu) $\log _{10} / \mathrm{g}$ of digesta were counted based on the colony morphology and characteristics of the particular bacteria. E. coli colonies were further subjected to $\mathrm{IMViC}$ reactions for further confirmation.

\section{Gut morphology}

Meckel's diverticulum was identified as a benchmark, $2 \mathrm{~cm}$ portion of jejunum was dissected, washed in normal saline solution, and fixed in 10\% neutral buffered formalin. Excessive fixation was removed by washing the tissues in running water followed by dehydration in ascending grades of alcohol as dehydrating agent. Dehydrating agent was cleared from tissues using pure xylene as clearing agent and infiltrated with melted paraffin wax as embedding agent. Afterwards, the jejunal tissues were embedded in paraffin blocks, six sections of $2 \mu \mathrm{m}$ were cut from paraffin block of each sample using a microtome. The gap between the sections of each block was maintained $100 \mu \mathrm{m}$. Three of the six $2 \mu \mathrm{m}$ sections were stained with hematoxylin and eosin after being mounted on the glass slides for histological analysis. In 
Ahsan U, Kuter E, Raza I, Köksal BH, Cengiz Ö, Yıldız M, Kızanlık PK, Kaya M, Tatlı O, Sevim Ö
Dietary Supplementation of Different Levels of Phytogenic Feed Additive in Broiler Diets: The Dynamics of Growth Performance, Caecal Microbiota, and Intestinal Morphometry order to enumerate the goblet cell number per villus, three remaining sections were stained with periodic Acid-Schiff (PAS) stain. The sections were observed under fluorescence microscope (Leica DMLB, Germany) coupled with digital imaging analysis system (Leica DC200, Germany). Villus height, villus diameter, crypt depth, and muscularis layer thickness were measured as 5 replications per section (15 measurements per bird) with the help of an image analysis program (Leica QWin Standard, Version 2.8, Germany). The goblet cell number per villus were counted manually in the middle $100 \mu \mathrm{m}$ portion of the PAS-stained sections.

\section{Statistical analysis}

Shapiro-Wilk's test was applied to test the normality of the data. Non-normalized traits were transformed using log or square root transformation. Data were statistically analysed with one-way analysis of variance in a completely randomized design using a computer statistical software package SPSS (Version 17.0; SPSS Inc., Chicago, IL, USA). Duncan's multiple range test was applied as a post-hoc test. Confidence interval was set at $95 \%(p<0.05)$. Results were presented as Mean \pm SEM.

\section{RESULTS}

The present study revealed that varying levels of dietary PFAs had no significant effect on growth performance (Table 2) and gut microbe populations (Table 3). However, the gut morphology was affected in response to dietary PFAs on 21 and 42 days of age

Table $\mathbf{2}$ - Rearing characteristics of broilers in response to different dietary levels of PFAs ( $n=8$ ).

\begin{tabular}{|c|c|c|c|c|c|c|c|c|c|}
\hline \multirow{2}{*}{ Treatments } & \multicolumn{3}{|c|}{ Body Weight Gain (g) } & \multicolumn{3}{|c|}{ Feed Intake (g) } & \multicolumn{3}{|c|}{ Feed Conversion Ratio } \\
\hline & d 1-21 & d 22-42 & d 1-42 & d 1-21 & d 22-42 & d 1-42 & d 1-21 & d 22-42 & d 1-42 \\
\hline Control & $1059 \pm 10.6$ & $1834 \pm 46.7$ & $2893 \pm 47.4$ & $1377 \pm 11.1$ & $3738 \pm 44.3$ & $5115 \pm 52.0$ & $1.30 \pm 0.01$ & $2.05 \pm 0.05$ & $1.77 \pm 0.02$ \\
\hline PFA100 & $1066 \pm 5.80$ & $1795 \pm 61.5$ & $2860 \pm 62.9$ & $1388 \pm 7.00$ & $3817 \pm 74.1$ & $5206 \pm 75.1$ & $1.30 \pm 0.01$ & $2.14 \pm 0.08$ & $1.83 \pm 0.04$ \\
\hline PFA125 & $1050 \pm 16.2$ & $1758 \pm 57.6$ & $2808 \pm 55.8$ & $1357 \pm 11.2$ & $3630 \pm 54.0$ & $4986 \pm 61.2$ & $1.30 \pm 0.02$ & $2.08 \pm 0.05$ & $1.78 \pm 0.02$ \\
\hline PFA150 & $1057 \pm 10.3$ & $1800 \pm 62.8$ & $2856 \pm 68.8$ & $1372 \pm 13.1$ & $3723 \pm 49.0$ & $5095 \pm 58.9$ & $1.30 \pm 0.01$ & $2.08 \pm 0.05$ & $1.79 \pm 0.03$ \\
\hline$p$-value & 0.802 & 0.831 & 0.788 & 0.241 & 0.161 & 0.125 & 0.960 & 0.715 & 0.599 \\
\hline
\end{tabular}

Table 3 - Total aerobes, coliforms, E. coli, and Lactobacilli count $\left(\log _{10} \mathrm{cfu} / \mathrm{g}\right)$ in caecaldigesta of broilers in response to different dietary levels of PFAs $(n=8)$.

\begin{tabular}{lcccccccc}
\hline \multirow{2}{*}{ Treatments } & \multicolumn{3}{c}{ Day 21} & \multicolumn{3}{c}{ Day 42 } \\
\cline { 2 - 8 } & Total Aerobes & Coliforms & E. coli & Lactobacilli & Total Aerobs & Coliforms & E. coli & Lactobacilli \\
\hline Control & $9.17 \pm 0.16$ & $6.89 \pm 0.23$ & $5.49 \pm 0.21$ & $7.11 \pm 0.08$ & $8.87 \pm 0.19$ & $7.68 \pm 0.16$ & $7.52 \pm 0.12$ & $8.07 \pm 0.15$ \\
PFA100 & $9.14 \pm 0.10$ & $7.00 \pm 0.20$ & $4.76 \pm 0.82$ & $7.20 \pm 0.26$ & $8.49 \pm 0.20$ & $7.46 \pm 0.31$ & $7.29 \pm 0.32$ & $8.43 \pm 0.13$ \\
PFA125 & $9.02 \pm 0.14$ & $7.10 \pm 0.18$ & $5.90 \pm 0.25$ & $7.31 \pm 0.17$ & $8.88 \pm 0.20$ & $7.54 \pm 0.21$ & $7.41 \pm 0.17$ & $8.72 \pm 0.15$ \\
PFA150 & $8.93 \pm 0.15$ & $6.62 \pm 0.38$ & $4.44 \pm 0.83$ & $7.29 \pm 0.28$ & $8.76 \pm 0.26$ & $7.95 \pm 0.33$ & $7.83 \pm 0.34$ & $8.49 \pm 0.23$ \\
\hline$p$-value & 0.616 & 0.589 & 0.274 & 0.883 & 0.551 & 0.585 & 0.492 & 0.110 \\
\hline
\end{tabular}

(Table 4 and 5). Villus height was significantly higher at $\mathrm{d} 21$ in broilers fed PFA150 diet compared to those fed the control diet (1086.47 vs $1019.69 \mu \mathrm{m} ; p<0.05)$. At $d$ 21, villus diameter (207.02 $\mu \mathrm{m})$ and crypt depth $(155.63 \mu \mathrm{m})$ were significantly lower and higher $(p<0.05)$ in broilers in the control group in comparison with other dietary treatments, respectively. Compared to the control group $(149.97 \mu \mathrm{m})$, dietary PFAs supplementation increased $(p<0.05)$ the muscularis thickness in PFA100 and PFA150 (166.40 and 163.18 $\mu m$, respectively) groups at $d 21$, whereas decreased in PFA125 group (139.22 $\mu$ m; $p<0.05)$. Goblet cell number was higher $(p<0.05)$ in PFA100 and PFA125 (11.63 and 11.76 , respectively) in comparison with control and PFA150 groups (10.81 and 10.37 , respectively) at $d 21$ of age. At $d 42$, broilers fed PFA125 diets

Table 4 - Villus height $(\mu \mathrm{m})$, villus diameter $(\mu \mathrm{m})$, crypt depth $(\mu \mathrm{m})$, muscularis thickness $(\mu \mathrm{m})$, and goblet cell number per villus of broilers on d 21 of experiment in response to different dietary levels of PFAs $(n=8)$.

\begin{tabular}{lccccc}
\hline Treatments & Villus Height & Villus Diameter & Crypt Depth & Muscularis Thickness & Goblet Cell Number \\
\hline Control & $1019.69 \pm 22.47^{\mathrm{b}}$ & $207.02 \pm 5.55^{\mathrm{c}}$ & $155.63 \pm 3.55^{\mathrm{a}}$ & $149.97 \pm 3.56^{\mathrm{b}}$ & $10.81 \pm 0.22^{\mathrm{b}}$ \\
PFA100 & $1037.56 \pm 20.71^{\mathrm{ab}}$ & $238.98 \pm 5.75^{\mathrm{b}}$ & $143.44 \pm 2.44^{\mathrm{c}}$ & $166.40 \pm 4.59^{\mathrm{a}}$ & $11.63 \pm 0.26^{\mathrm{a}}$ \\
PFA125 & $1074.96 \pm 20.75^{\mathrm{ab}}$ & $262.49 \pm 6.48^{\mathrm{a}}$ & $145.97 \pm 3.05^{\mathrm{ab}}$ & $139.22 \pm 3.25^{\mathrm{c}}$ & $11.76 \pm 0.24^{\mathrm{a}}$ \\
PFA150 & $1086.47 \pm 11.27^{\mathrm{a}}$ & $235.86 \pm 5.50^{\mathrm{b}}$ & $153.97 \pm 2.71^{\mathrm{bc}}$ & $163.18 \pm 2.93^{\mathrm{a}}$ & $10.37 \pm 0.20^{\mathrm{b}}$ \\
\hline$p$-value & $<0.05$ & $<0.001$ & 0.008 & $<0.001$ & $<0.001$ \\
\hline
\end{tabular}

$a, b, c$ Means bearing different superscripts within the same column differ significantly. 
Ahsan U, Kuter E, Raza I, Köksal BH, Cengiz Ö, Yıldız M, Kızanlık PK, Kaya M, Tatlı O, Sevim Ö
Dietary Supplementation of Different Levels of Phytogenic Feed Additive in Broiler Diets: The Dynamics of Growth Performance, Caecal Microbiota, and Intestinal Morphometry

Table 5 - Villus height $(\mu \mathrm{m})$, villus diameter $(\mu \mathrm{m})$, crypt depth $(\mu \mathrm{m})$, muscularis thickness $(\mu \mathrm{m})$, and goblet cell number per villus of broilers on d 42 of experiment in response to different dietary levels of PFAs $(n=8)$.

\begin{tabular}{lccccc}
\hline Treatments & Villus Height & Villus Diameter & Crypt Depth & Muscularis Thickness & Goblet Cell Number \\
\hline Control & $1066.35 \pm 18.12^{\mathrm{b}}$ & $141.24 \pm 3.67^{\mathrm{b}}$ & $168.36 \pm 3.17^{\mathrm{b}}$ & $178.43 \pm 3.51^{\mathrm{b}}$ & $10.53 \pm 0.22^{\mathrm{b}}$ \\
PFA100 & $987.80 \pm 19.78^{\mathrm{c}}$ & $188.86 \pm 6.75^{\mathrm{a}}$ & $171.55 \pm 3.69^{\mathrm{b}}$ & $201.08 \pm 4.97^{\mathrm{a}}$ & $11.59 \pm 0.26^{\mathrm{a}}$ \\
PFA125 & $1155.43 \pm 21.20^{\mathrm{a}}$ & $173.13 \pm 8.88^{\mathrm{a}}$ & $166.10 \pm 4.09^{\mathrm{b}}$ & $204.81 \pm 5.95^{\mathrm{a}}$ & $10.51 \pm 0.28^{\mathrm{b}}$ \\
PFA150 & $1017.70 \pm 18.68^{\mathrm{bc}}$ & $186.04 \pm 5.97^{\mathrm{a}}$ & $192.42 \pm 4.45^{\mathrm{a}}$ & $179.38 \pm 3.75^{\mathrm{b}}$ & $10.41 \pm 0.22^{\mathrm{b}}$ \\
\hline$p$-value & $<0.001$ & $<0.001$ & $<0.001$ & $<0.001$ & $<0.001$ \\
\hline
\end{tabular}

$a, b, c$ Means bearing different superscripts within the same column differ significantly.

had higher villus height compared to control group (1155.43 vs $1066.35 \mu \mathrm{m} ; p<0.05)$. Villus diameter and crypt depth were lowest and highest in control and PFA150 groups, respectively, compared to other dietary treatments at $d 42 \quad(p<0.05)$. Muscularis thickness increased significantly in PFA100 and PFA125 groups (201.08 and $204.81 \mu \mathrm{m}$, respectively) in comparison with control and PFA150 groups (178.43 and 179.38 $\mu \mathrm{m}$, respectively; $p<0.05)$. Similarly, supplementation of PFAs in PFA100 group (11.59) increased the goblet cell number as compared to other dietary treatments at $\mathrm{d} 42(p<0.05)$.

\section{DISCUSSION}

The availability of a vast variety of phytogenic products comprising of various bioactive molecules and active ingredients in the market makes the comparison of the results of the scientific investigations very difficult. In this study, a blend of different spices, and essential oils was used which made it even harder to interpret the role of each component in the blend for the results obtained. Therefore, the interpretation of results requires attention to these facts.

The present study showed that BWG, Fl, and FCR of broilers were not statistically different among the treatments. These results are no different than those reported by Botsoglu et al. (2002) and Lee et al. (2004) who found that dietary supplementation of oregano essential oil (100 and $50 \mathrm{mg} / \mathrm{kg}$, respectively) did not affect the broilers' performance. Fukayama et al. (2005) reported that growth performance of broilers remained unaffected following the dietary supplementation of oregano extract at 0, 25, 50, 75 , and $100 \mathrm{mg} / \mathrm{kg}$. Similarly, dietary addition of 250 and 500 ppm phytogenic feed additive (based on essential oils of oregano (carvacrol), cinnamon (cinnamaldehyde), eucalyptus (cineole/eucalyptol), artemisia (artemisinin), and clover (trifoline)) had no effect on growth performance of broilers (Toledo et al., 2007). Dietary supplementation of 250 ppm garlic based PFAs (organopolysulphide compounds) did not improve the growth performance of broilers (Kumar et al., 2010). Rizzo et al. (2010) concluded that broilers fed diets supplemented with 1000 ppm of PFA (based on $20 \%$ active ingredients as essential oils of clove, thyme, cinnamon, and capsicum) or 100 ppm of PFA (based on essential oils of oregano and cinnamon, and capsicum oleoresin) or 500 ppm of PFA (containing eucalyptus oil, Chinese cinnamon oil, Chilean boldo leaves, and fenugreek seeds) had no difference in growth performance. Likewise, supplemental PFA containing turmeric extract, citrus extract, grape seed extract, Chinese cinnamon essential oil, Chilean boldo leaves, and fenugreek seeds had no effect on growth performance of broilers (Fascina et al., 2012). Similar findings were reported by Abudabos \& Alyemni (2013) in broilers fed $0.01 \%$ of a blend of essential oils including 29\% active ingredients (piperine, curcumin, thymol, and eugenol). Hafeez et al. (2016) reported that growth performance was not different in broilers fed diets supplemented with $100 \mathrm{mg} / \mathrm{kg}$ PFA (based on carvacrol, thymol, limonene) or $150 \mathrm{mg} /$ kg PFA (based on menthol and anethole), or without supplementation. Abildgaard et al. (2010) reported that broilers fed diets without the blend of essential oils ( $0 \mathrm{mg} / \mathrm{kg}$ ) had better growth performance than those fed 100, and $200 \mathrm{mg} / \mathrm{kg}$ of a blend of essential oils containing thymol, eugenol, piperine, and curcumin. In contrast, some other studies showed that dietary PFAs supplementation improved the performance of broilers. Jamroz et al. (2005) reported that the inclusion of 100 mg PFAs (containing carvacrol, cinnamaldehyde, and capsicum oleoresin) per $\mathrm{kg}$ of the diet improved the performance of broilers. Spernakova et al. (2007) reported similar findings in broilers fed rosemary powder at $500 \mathrm{mg} / \mathrm{kg}$ of the diet. Fortification of broiler diet with a blend of phytogenic extracts at 1 $\mathrm{g} / \mathrm{kg}$ also increased the BW gain and enhanced the performance (Lippens et al., 2005). Similarly, the dietary supplementation of $1 \mathrm{~g} / \mathrm{kg}$ thyme essential oil (Cross et al., 2007) and $5 \mathrm{~g} / \mathrm{kg}$ thyme herb (Toghyani et al., 2010) improved the performance of broilers. The actual mechanism of action by which PFAs improve 
Ahsan U, Kuter E, Raza I, Köksal BH, Cengiz Ö, Yıldız M, Kızanlık PK, Kaya M, Tatlı O, Sevim Ö
Dietary Supplementation of Different Levels of Phytogenic Feed Additive in Broiler Diets: The Dynamics of Growth Performance, Caecal Microbiota, and Intestinal Morphometry the performance of broilers is not known, however, it may be due to the stabilization of feed components, improvement of the gut environment, concentration of enviable microflora or by the continuous stimulation of pancreatic and the digestives enzymes (Windisch et al., 2008). Apparently, the variation in the results of the present study compared to previous studies seems to occur due to the differences in a number of factors. The variation in the efficacy of PFAs may arise due to the difference in the selection of plants that possess various bioactive biomolecules. In addition, the use of different parts of the plants may influence the results as well as the variations in the effectiveness of PFAs supplemented to the poultry diets. Most studies do not mention the concentration of active ingredients in PFA rather they list the active ingredients or the name of the components only. Therefore, it is very hard to make a comparison on the basis of the concentration of the active ingredient. However, the difference in the composition of PFAs suggests the difference in the results. Moreover, it is more likely that the concentration of the bioactive molecules would vary greatly among the PFAs in addition to the extracts or essential oils of the plants used that lead towards an inconsistency in the concentration of the bioactive molecules in PFAs. Additionally, the inclusion level of PFAs may play an important role. Most of the studies have used the mixture of different plant extracts, essential oil, herbs, and spices. Only fewer studies have emphasized the use of individual plant or its extracts. The quantity of the bioactive molecules in an individual plant has been an unsolved question. This implies that the exact inclusion level cannot be reached until the quantification of bioactive molecules in the individual plant is not accomplished in order to determine the effective level of application in poultry diets. It is important that the composition of the diet as well as the genetic potential of the broilers determine the efficacy of PFAs. Another possibility is that the components of PFAs used in the present study might have behaved differently resulting in failure to improve the growth performance of broilers. It is speculated that the diets used in the present study would have been successful to fully express the genetic potential for growth performance of broilers not leaving any room for further dietary supplementation of PFAs to improve the growth performance of broilers.

Most studies have reported a decrease in the pathogenic bacteria such as coliforms, E. coli, C. perfringens, and Salmonella spp. and improvement in lactobacilli populations in the intestines of broilers (Jamroz et al., 2003; 2005; Mitsch et al., 2004; Jang et al., 2007; Siragusa et al., 2008; McReynolds et al., 2009; Murugesan et al., 2015; Wati et al., 2015; Manafi et al., 2016). Only a few studies reported that dietary PFAs supplementation were unable to reduce the total aerobic and anaerobic bacteria, E. coli, Clostridium spp., C. jejuni, and improve the lactobacilli, and bifidobacteria populations in the broilers (Peric et al., 2010; Hermans et al., 2011; Vukic-Vrajnes et al., 2013; Mountzouris et al., 2014). The present study showed that dietary PFAs supplementation were ineffective to the selected caecal microbial populations. Usually, the antimicrobial activity of PFAs is attributed to the presence of the volume of essential oils in it. According to Hammer et al. (1999), most essentials oils showed their in vitro antimicrobial activity at an inclusion level ranging from 0.03 to $2.0 \%(\mathrm{v} / \mathrm{v})$. However, the essential oils are supplemented in feed at lower levels than those required for their in vitro antimicrobial activity (Hafeez et al., 2016). This might have occurred in the present study. The gut microbiota of broilers becomes more stable against changes as the age progresses compared to the younger chicks (Torok et al., 2009). This might be another reason for the failure of dietary PFAs to improve the caecal microbial population of broilers in the present study. The molecular study on gut microbiome of broilers might present the true picture of dynamics of gut microbiota of broilers following dietary supplementation of PFAs.

In this study, dietary supplementation of PFAs significantly affected the villus height and diameter, crypt depth, muscularis thickness, and goblet cell number per villus in the jejunal sections of broilers in comparison with the control group on 21 and 42 days of age. Overall, villus height, diameter, and goblet cell number increased whereas crypt depth and muscularis thickness decreased in response to the dietary PFAs. This shows a promising effect of PFAs on gut health of broilers. The increased villus height and villus diameter are linked with increased surface area which, in turn, leads to better digestion and absorption (Murugesan et al., 2014). Similarly, a higher number of goblet cell per villus indicates higher production of mucins and glycoprotein compounds that bind with the pathogenic bacteria thus preventing their attachment with the intestinal mucosa (Chacher et al., 2017). The intestinal crypts act as a reservoir of epithelial cells so they are indicative of epithelial cell turnover or renewal rate. The cell turnover is a nutrient consuming process that uses vital nutrients that would otherwise be consumed for growth (Markovic et al., 2009). Muscularis thickness reveals the germ load in broiler's intestine. 
Ahsan U, Kuter E, Raza I, Köksal BH, Cengiz Ö, Yıldız M, Kızanlık PK, Kaya M, Tatlı O, Sevim Ö
Dietary Supplementation of Different Levels of Phytogenic Feed Additive in Broiler Diets: The Dynamics of Growth Performance, Caecal Microbiota, and Intestinal Morphometry
Shallow crypts and thin muscularis show that the bird has lower germ load indicating that it might spare nutrients for growth. The results of gut morphology in the present study suggest that dietary PFAs would have improved performance and gut microbiota in broilers that actually did not occur. It might be suggestive of low levels of essential oils in the phytogenic product used in this study. It is speculated that the inclusion levels used in the present study might be sufficient to improve the gut morphometry of broilers and higher inclusion levels might be needed for improvement in growth performance and caecal microbial populations.

\section{CONCLUSIONS}

The present study has shown the results quite different from those previously reported by different researchers on the effect of PFAs on growth performance, gut morphology, and gut microbiota of broilers. The study revealed that the different levels of dietary PFAs supplementation in broilers improved the gut morphology only despite most studies reporting the improvement of growth performance and gut microbiota, and only afewstudies showing improvement in the gut morphology of broilers. Since the in vitro studies have shown that antimicrobial activity of PFAs requires a higher concentration of essential oils that is not in practice while applying in the feeds. Therefore, higher inclusion levels of the phytogenic product may be helpful in enhancing the growth performance and gut microbiota of broilers. Furthermore, under the conditions of the present study, the inclusion rate of dietary PFAs may be different for different criteria e.g. enhancing the growth performance, and improving the gut microbiota and gut morphology.

\section{ACKNOWLEDGEMENTS}

The authors are grateful to the Scientific and Technological Research Council of Turkey (TÜBITAK) for the award of master and doctoral fellowship to Umair Ahsan under BiDEB-2215 graduate scholarship program for international students. Sincere thanks are extended to directorate of scientific projects (BAP) (project No. VTF-16009) of Adnan Menderes University, and Biokey Ltd. Şti. for the financial support to carry out this research work.

\section{CONFLICT OF INTEREST}

The authors declare that there is no conflict of interest.

\section{REFERENCES}

Abildgaard L, Hoijberg O, Schramm A, Balle KM, Engberg RM. The effect of feeding a commercial essential oil product on Clostridium perfringens numbers in the intestine of broiler chickens measured by real-time PCR targeting the $\alpha$-toxin- enconding gene (plc). Animal Feed Science and Technology 2010;157:181-9.

Abudabos AM, Alyemni AH. Effects of the essential oil blend CRINA® Poultry in feed on broiler performance and gut microbiology. Italian Journal of Animal Science 2013;12:e83 Available from: doi:10.4081/ ijas.2013.e83

Ahsan U, Cengiz Ö, Raza I, Kuter E, Chacher MFA, Iqbal Z, et al. Sodium butyrate in chicken nutrition:the dynamics of performance, gut microbiota, gut morphology, and immunity. World's Poultry Science Journal 2016;72:265-275.

Amad AA, Männer K, Wendler KR, Neumann K, Zentek J. Effects of a phytogenic feed additive on growth performance and ileal nutrient digestibility in broiler chickens. Poultry Science 2011;90;2811-6.

Applegate TJ, Klose V, Steiner T, Ganner A, Schatzmayer G. Probiotics and phytogenics for poultry:myth or reality? Journal ofApplied Poultry Research 2010;19:194-210.

Aviagen. Ross 308 broiler: nutrition specifications. 2014. p.1-10. Available from: http://eu.aviagen.com/assets/Tech_Center/Ross_Broiler/Ross308-Broiler-Nutrition-Specs-plant-2014-EN.pdf.

Botsoglou NA, Florou-Paneri P, Christaki E, Fletouris DJ, Spais AB. Effect of dietary oregano essential oil on performance of chickens and on iron-induced lipid oxidation of breast, thigh and abdominal fat tissues. British Poultry Science 2002;43:223-230.

Brenes A, Roura E. Essential oils in poultry nutrition: main effects and modes of action. Animal Feed Science and Technology 2010;158:1-14.

Buchanan, NP, Hott JM, Cutlip SE, Rack AL, Asamer A, Moritz JS. The effects of a natural antibiotic alternative and a natural growth promoter feed additive on broiler performance and carcass quality. Journal of Applied Poultry Research 2008; 17:202-210

Burt S. Essential oils: their antibacterial properties and potential applications in foods-a review. International Journal of Food Microbiology 2004;94:223-253.

Cengiz O, Koksal BH, Tatli O, Sevim O, Avci H, Epikmen T, et al. Influence of dietary organic acid blend supplementation and interaction with delayed feed access after hatchon broiler growth performance and intestinal health. Veterinarni Medicina 2012;57:515-528.

Chacher MFA, Kamran Z, Ahsan U, Ahmad S, Koutoulis KC, Qutab Ud Din $\mathrm{HG}$, et al. Use of mannan oligosaccharide in broiler diets:an overview of underlying mechanisms. World's Poultry Science Journal 2017;73:831844 .

Ciftci M, Güler T, Dalkiliç B, Ertas ON. The effect of anise oil (Pimpinellaanisum L.) on broiler performance. International Journal Poultry Science 2005; 4:851-855

Cross DE, McDevitt RM, Hillman K, Acamovic T. The effect of herbs and their associated essential oils on performance, dietary digestibility and gut microflora in chickens 7 to $28 \mathrm{~d}$ of age. British Poultry Science 2007;48:496-506.

Cross DE, Svoboda K, McDevitt RM, Acamovic T. The performance of chickens fed diets with or without thyme oil and enzymes. British Poultry Science 2003;44:18-19.

Daferera DJ, Ziogas BN, Polissiou MG. The effectiveness of plant essential oils on Botrytis cinerea, Fusarium sp. and Clavibactermichiganensis subsp. michiganensis. Crop Protection 2003;22:39-44. 
Ahsan U, Kuter E, Raza I, Köksal BH, Cengiz Ö, Yıldız M, Kızanlık PK, Kaya M, Tatlı O, Sevim Ö

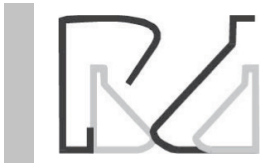

Dibner JJ, Richards JD. Antibiotic growth promoters in agriculture:History and mode of action. Poultry Science 2005;84:634-643.

Fascina VB, Sartori JR, Gonzales E, Barros de Carvalho F, Pereira de Souza IMG, Polycarpo GV, et al. Phytogenic additives and organic acids in broiler chicken diets. Revista Brasileira de Zootecnia 2012;41:21892197.

Fries R, Akcan M, Bandick N, Kobe A. Microflora of two different types of poultry litter. British Poultry Science 2005;46:668-672.

Fukayama EH, Bertechini AG, Geraldo A, Kato RK, Murgas LDS. Extrato de orégano como aditivo em rações para frangos de corte. Revista Brasileira de Zootecnia 2005;34:2316-2326

Hafeez A, Manner K, Schieder C, Zentek J. Effect of supplementation of phytogenic feed additives (powdered vs. encapsulated) on performance and nutrient digestibility in broiler chickens. Poultry Science 2016;95:622-629

Hammer KA, Carson CF, Riley TV. Antimicrobial activity of essential oils and other plant extracts. Journal of Applied Microbiology 1999;86:985990.

Hermans D, Martel A, van Deun K, van Immerseel F, Heyndrickx M, et al. The cinnamon-oil ingredient trans-cinnamaldehyde fails to target Campylobacter jejunistrain KC 40 in the broiler chicken cecum despite marked in vitro activity. Journal of Food Protection 2011;74:17291734

Hernandez F, Madrid J, Garcia V, Orengo J, Megias MD. Influence of two plant extracts on broiler performance, digestibility, and digestive organ size. Poultry Science 2004;85:1466-1471.

Hippenstiel F, Abdel-Wareth AAA, Kehraus S, Sudekum KH. Effects of selected herbs and essential oils, and their active components on feed intake and performance of broilers - a review. Archivfür Geflügelkunde $2011 ; 75: 226-234$

Hong JC, Steiner T, Aufy A, Lien TF. Effects of supplemental essential oil on growth performance, lipid metabolites and immunity, intestinal characteristics, micro biota and carcass traits in broilers. Livestock Science 2012;144:253-262.

Jamroz D, Kamel C. Plant extracts enhance broiler performance. Journal of Animal Science 2002;80(Suppl. 1):41. (Abstract)

Jamroz D, Orda J, Kamel C, Wiliczkiewicz A, Wertelecki T, Skorupinska J. The influence of phytogenic extracts on performance, nutrient digestibility, carcass characteristics, and gut microbial status in broiler chickens. Journal of Animal and Feed Sciences 2003;12:583-596.

Jamroz D, Wiliczkiewicz A, Wertelecki T, Orda J, Scorupinska J. Use of active substances of plant origin in chicken diets based on maize and domestic grains. British Poultry Science 2005;46:485-493.

Jang IS, Ko YH, Kang SY, Lee CY. Effect of commercial essential oils on growth performance, digestive enzyme activity, and intestinal microflora population in broiler chickens. Animal Feed Science and Technology 2007;134:304-315.

Jayalakshmi T, Kumararaj R, Sivakumar T, Vanan TT, Thiagarajan D. Influence of stocking densities on litter moisture, microbial load, air ammonia concentration and broiler performance. Tamilnadu Journal of Veterinary and Animal Science 2009;5:80-86.

Kabir SML. The role of probiotics in the poultry industry. International Journal of Molecular Sciences 2009:10:3531-3546.

Kumar S, Sharadamma KC, Radhakrishna PM. Effects of a garlic active based growth promoter on growth performance and specific pathogenic intestinal microbial counts of broiler chicks. International Journal of Poultry Science 2010;9:244-246.
Dietary Supplementation of Different Levels of Phytogenic Feed Additive in Broiler Diets: The Dynamics of Growth Performance, Caecal Microbiota, and Intestinal Morphometry

Lee $\mathrm{K}$, Everts $\mathrm{H}$, Beynen A. Essential oils in broiler nutrition. International Journal of Poultry Science 2004;3:738-752

Lee KW, Everts H, Kappert HJ, van der Kuilen J, Lemmers AG, Frehner M, et al. Growth performance, intestinal viscosity, fat digestibility and plasma cholesterol in broiler chickens fed a rye-containing diet without or with essential oil components. International Journal of Poultry Science 2003a;3:613-618.

Lee KW, Everts H, Kappert HJ, Yeom KH, Beynen AC. Dietary carvacrol lowers body weight gain but improves feed conversion in female broiler chickens. Journal of Applied Poultry Research 2003b;12:394-399.

Lee KW, Everts H, Kappert HJ, Frehner M, Losa R, Beynen AC. Effects of dietary essential oil components on growth performance, digestive enzymes and lipid metabolism in female broiler chickens. British Poultry Science 2003c;44:450-457.

Lippens M, Huyghebaert G, Cerchiari E. Effect of the use of coated plant extracts and organic acids as alternatives for antimicrobial growth promoters on the performance of broiler chickens. ArchivfürGeflügelkunde 2005;69:261-266.

Manafi M, Hedayati M, Khalaji S. Effectiveness of phytogenic feed additive as alternative to bacitracin methylene disalicylate on haematological parameters,intestinal histomorphology and microbial population andproduction performance of japanese quails. Asian-Australasian Journal of Animal Sciences 2016;29:1300-1308.

Markovic R, Sefer D, Krstic M, Petrujkic B. The effect of different growth promotors on broiler performance and gut morphology. Archivos de MedicinaVeterinaria2009;41:163-169.

McReynolds J, Waneck C, Byrd J, Genovese K, Duke S, Nisbet D. Efficacy of multistrain direct-fed microbial and phytogenic products in reducing necrotic enteritis in commercial broilers. Poultry Science 2009;88:20752080

Mitsch P, Zitterl-Eglseer K, Köhler B, Gabler C, Losa R, Zimpernik I. The effect of two different blends of essential oil components on the proliferation of Clostridium perfringens in the intestines of broiler chickens. Poultry Science 2004;83:669-675.

Mountzouris KC, Paraskevas V, Tsirtsikos P, Palamidi I, Steiner T, Schatzmayr $\mathrm{G}$, et al. Assessment of a phytogenic feed additive effect on broiler growth performance, nutrient digestibility and caecal microflora composition. Animal Feed Science and Technology 2011;168:223-231.

Mountzouris KC, Tsirtsikos P, Papadomichelakis G, Schatzmayr G, Fegeros $K$. Evaluation of the efficacy of sequential or continuous administration of probiotics and phytogenics in broiler diets. Animal Production Science 2014;55:720-728.

Muhl A, Liebert F. Growth, nutrient utilization and threonine requirement of growing chicken fed threonine limiting diets with commercial blends of phytogenic feed additives. The Journal of Poultry Science 2007;44:297-304.

Murugesan GR, Gabler NK, Persia ME. Effects of direct-fed microbial supplementation on broiler performance, intestinal nutrient transport and integrity under experimental conditions with increased microbial challenge. British Poultry Science 2014;55:89-97.

Murugesan GR, Syed B, Haldar S, Pender C. Phytogenic feed additives as an alternative to antibiotic growth promoters in broiler chickens. Frontiers in Veterinary Science 2015;2:21. Available from: doi:10.3389/ fvets.2015.00021

Peric L, Milosevic N, Zikic D, Bjedov S, Cvetkovic D, Markov S, et al. Effects of probiotic and phytogenic products on performance, gut morphology and cecal microflora of broiler chickens. Archives Animal Breeding 2010;3:350-359. 
Ahsan U, Kuter E, Raza I, Köksal BH, Cengiz Ö, Yıldız M, Kızanlık PK, Kaya M, Tatlı O, Sevim Ö

Puvaca N, Stanacev V, Glamocic D, Levic J, Peric L, Stanacev V, et al. Beneficial effects of phytoadditives in broiler nutrition. World's Poultry Science Journal 2013;69:27-34.

Puvaca N. Effect of phytoadditive (Allium sativum L.) in fattening chicks nutrition. Proceedings of the $32^{\text {nd }}$ International Conference of Agriculture; 2008; Novi Sad. Serbia. p.116-221.

Reisinger N, Steiner T, Nitsch S, Schatzmayr G, Applegate TJ. Effects of a blend of essential oils on broiler performance and intestinal morphology during coccidial vaccine exposure. The Journal of Applied Poultry Research 2011;20:272-283.

Rizzo PV, Menten JFM, Racanicci AMC, Traldi, AB, Silva CS, Pereira PWZ. Extratos vegetais em dietas para frangos de corte. Revista Brasileira de Zootecnia 2010;39:801-807.

Ruberto G, Barrata M, Sari M, Kaabehe M. Chemical composition and antioxidant activity of essential oils from Algerian Origanum glandulosum Desf. Flavour and Fragrance Journal 2002;17:251-254.

Siragusa GR, Haas GJ, Matthews PD, Smith RJ, Buhr RJ, Dale NM, et al. Antimicrobial activity of lupulone against Clostridium perfringens in the chicken intestinal tract jejunum and caecum. Journal of Antimicrobial Chemotherapy 2008;61:853-858.

Spernakova D, Mate D, Rozanska H, Kovac G. Effect of dietary rosemary extract and $\alpha$-tocopherol on the performance of chickens, meat quality, and lipid oxidation in meat storage under chilling conditions. Bulletin of Veterinary Institute in Pulawy 2007;51:585-589.

Toghyani M, Tohidi M, Gheisari AA, Tabeidian SA. Performance, immunity, serum biochemical and hematological parameters in broiler chicks fed dietary thyme as alternative for an antibiotic growth promoter. African Journal of Biotechnology 2010;9:6819-6825.
Dietary Supplementation of Different Levels of Phytogenic Feed Additive in Broiler Diets: The Dynamics of Growth Performance, Caecal Microbiota, and Intestinal Morphometry

Toledo GSP, Costa PTC, Silva LP, Pinto D, Ferreira P, Poletto CJ. Desempenho de frangos de corte alimentados com dietas contend antibiótico e/ ou fitoterápico como promotores, adicionados isoladamente ou associados. Ciência Rural 2007;37:1760-1764.

Torok VA, Hughes RJ, Ophel-Keller K, Ali M, MacAlpine R. Influence of different litter materials on cecal microbiota colonization in broiler chickens. Poultry Science 2009;88:2474-2481.

Vesna T, Lazarević M, Sinovec $Z$, Tokić A. The influence of different feed additives to performances and immune response in broiler chicken. Acta Veterinaria 2007;57:217-229.

Vukic-Vrajnes M, Tolimir N, Vukmirovic D, Colovic R, Stanacev V, Ikonic P, Pavkov S. Effect of phytogenic additives on performance, morphology and caecal microflora of broiler chickens. Biotechnology in Animal Husbandry 2013;29:311-319.

Wati T, Ghosh TK, Syed B, Haldar S. Comparative efficacy of a phytogenic feed additive and an antibiotic growth promoter on production performance, caecal microbial population and humoral immune response of broiler chickens inoculated with enteric pathogens. Animal Nutrition 2015;1:213-219.

Windisch WM, Schedle K, Plitzner C, Kroismayr A. Use of phytogenic products as feed additives for swine and poultry. Journal of Animal Science 2008;86(14 Suppl.):E140-E148.

Yang $Y$, lji PA, Choct M. Dietary modulation of gut microflora in broiler chickens:a review of the role of six kinds of alternatives to in-feed antibiotics. World's Poultry Science Journal 2009;65:97-114.

Yitbarek MB. Phytogenics as feed additives in poultry production: a review. International Journal of Extensive Research 2015;3:49-60. 
